\title{
Gorontalo
}

\author{
J ournal of Govemment andPditica Studies \\ Volume 2 - N0. 2 - Oktober 2019 \\ P-ISSN: 2614-2120 E-ISSN: 2614-2104
}

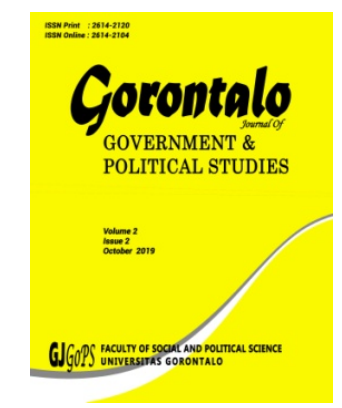

\section{Efektivitas Penerapan E-Government di Kabupaten Mamuju, Provinsi Sulawesi Barat}

\author{
Muhlis Zainuddin \\ Universitas Tomakaka Mamuju \\ Mamunyu, Kec. Mamuju, Kabupaten Mamuju, Sulawesi Barat 91511 \\ muhliszain@gmail.com
}

Received: 6th July 2019; Revised: 6th September 2019;

Accepted: 6th September 2019;

\begin{abstract}
Information and Communication Technology has become a basic need in people's lives and services by the government. The government as the executor of public services uses $e$ Government as a means and infrastructure to realize effective, efficient and accountable. The application of e-Government in each district / city has a different level of effectiveness, so research needs to be done to improve and determine the future direction. This research was conducted in Mamuju District, West Sulawesi Province. This research approach is descriptive by using a type of qualitative research that aims to analyze the results of data processing based on theoretical indicators. Data collection techniques are carried out by in-depth interviews, observations, and documentation studies. Data analysis techniques with data reduction, data presentation and conclusion / verification with triangulation theory, which underlies the theory of The Four Forces Model of e-Government, research in the field, and data analysis to draw conclusions. The results showed that the implementation of e-Government in Mamuju District was not yet effective. Of the twelve indicators only four indicators are met. Not Achieving Effectiveness The application of e-Government in Mamuju Regency is caused by a lack of understanding of $e$-Government at the executive level, regional officials, technical officials, and legislative officials and most of the community. The lack of Human Resources (HR) in the field of Information Technology (IT) is a very big obstacle to the application of $e^{-}$ Government in Mamuju District.
\end{abstract}

Keywords: Effectiveness; E-Government; The Four Forces Model

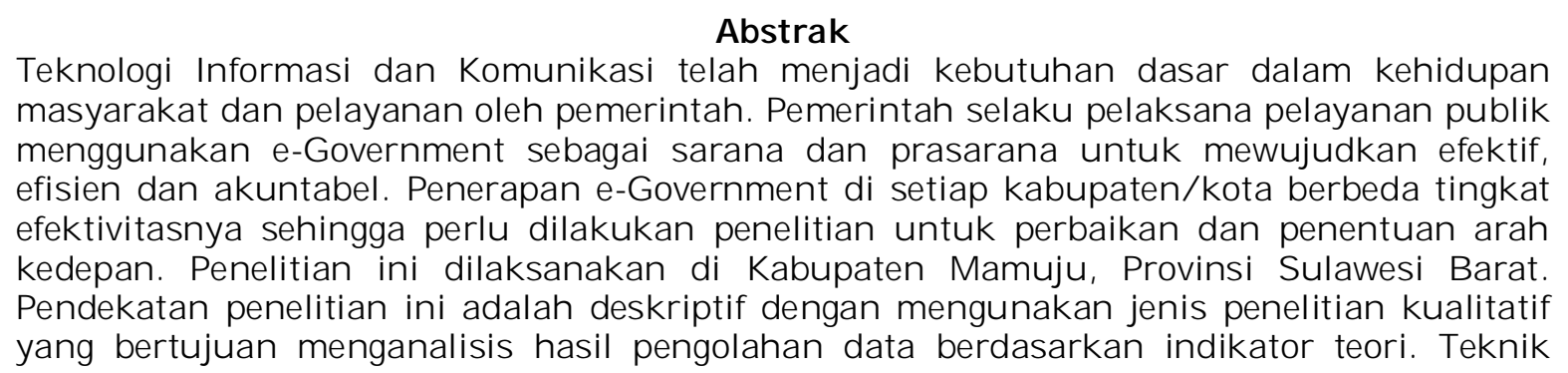


GJGOPS

P-ISSN: 2614-2120, E-ISSN: 2614-2104

pengumpulan data dilakukan dengan cara wawancara mendalam, observasi, dan studi dokumentasi. Teknik analisis data dengan reduksi data, penyajian data dan pengambilan kesimpulan/verifikasi dengan triangulasi teori, yaitu mendasari teori The Four Forces Model of e-Goverrnent, penelitian di lapangan, dan analisis data untuk mengambil kesimpulan. Hasil penelitian menunjukkan bahwa penerapan e-Government di Kabupaten mamuju belum efektif. Dari dua belas indikator hanya empat indikator yang terpenuhi. Tidak tercapainya Efektivitas Penerapan e-Government di Kabupaten mamuju disebabkan karena kurangnya pemahaman tentang e-Government pada tingkat eksekutif, pejabat organisasi perangkat daerah, pejabat teknis, dan pejabat legislatif serta sebagian besar masyarakat. Kurangnya Sumber Daya Manusia (SDM) dalam bidang Information Technology (IT) menjadi hambatan yang sangat besar terhadap penerapan e- Governent di Kabupaten Mamuju.

Keywords: Efektivitas; E-Governrnent; The Four Forces Model

\section{PENDAHULUAN}

Teknologi Informasi dan Komunikasi telah menjadi kebutuhan dasar dalam kehidupan masyarakat dan pelayanan oleh pemerintah. Pemerintah selaku pelaksana pelayanan publik menggunakan eGovernment sebagai salah satu sarana dan prasarana untuk mewujudkan pelayanan yang lebih efektif, efisien dan akuntabel terhadap masyarakat. E-Government oleh Indrajit (2006) diartikan sebagai suatu mekanisme interaksi baru antara pemerintah dengan masyarakat dan kalangan lain yang berkepentingan, dengan melibatkan penggunaan teknologi informasi (terutama internet) dengan tujuan memperbaiki mutu (kualitas) pelayanan.

Penggunaan elekronik dalam lingkungan pemerintah Indonesia dimulai pada tahun 1995 dengan nama Bina Graha Net yang berlokasi di Istana Negara di Jakarta. Dasar pelaksanaan e-Government dalam lingkup pemerintah daerah di Indonesia yakni (1) Instruksi Presiden Nomor 3 Tahun 2003 tentang Kebijakan dan Strategi Nasional Pengembangan e-Government;

(2) Keputusan Menkominfo No. 55 Tahun 2003 tentang Panduan Pembangunan Infrastuktur Portal Pemerintah; dan (3) Cetak Biru Sistem Aplikasi e-Government bagi Pemerintah Pusat dan Daerah oleh Departemen Komunikasi dan Informatika, 2006.

Di Kabupaten Kepulauan Mamuju e-Government mulai dilaksanakan pada tahun 2004 dengan pembangunan infrastruktur elektronik yang mencakup pengadaan perangkat komputer dan jaringan intranet lingkup Pemerintah Kabupaten Kepulauan Mamuju. Dalam observasi awal yang peneliti lakukan pada Sekretariat Daerah Kabupaten Mamuju, Bagian Komunikasi Informatika, Statistik dan Persandian, diperoleh informasi bagaimana konsep e- Government sesuai pemahaman pemerintah dan sejauh mana pelaksanaan kegiatan-kegiatan e-Government pada tingkat kabupaten. Belum ada produk hukum daerah baik itu Peraturan Daerah atau Peraturan Bupati terkait e-Government sejak awal pelaksanaanya 
pada tahun 2004. Dari sisi kelembagaan atau organisasi juga belum ada Organisasi Perangkat Daerah yang melaksanakan kegiatan satu konsep e-Government yang seharusnya pada tahun 2016 berada pada Dinas Perhubungan dan Komunikasi Informatika atau pada tahun 2017 pada Bagian Komunikasi, Informatika, Statistik dan Persandian. Infrastruktur e-Government juga dibangun secara parsial karena mengikuti kegiatan yang tertuang dalam APBD. Website dan aplikasi juga dibangun secara parsial tanpa ada interkoneksi dalam satu konsep e- Government, ini terlihat pada Bagian Kominfo-SP yang tidak memiliki server aktif baik itu dikelola sendiri maupun yang dipihak ketigakan serta website yang belum memiliki data standar untuk pelayanan.

Berdasarkan pemaparan kodisi faktual, berbagai fenomena dan untuk menentukan langkah perbaikan ke depan terkait e-Government di Kabupaten Kepulauan Mamuju maka perlu diteliti Efektivitas Penerapan e-Government di Kabupaten Kepulauan Mamuju dengan menggunakan teori yang relevan dengan masalah tersebut. Penelitian Efektivitas Penerapan e- Government di Kabupaten mamuju ini menggunakan kriteria e-Government sebagai tujuan dari target yang ingin dicapai oleh Pemerintah Kabupaten Mamuju. Pengukurannya kriterianya menggunakan empat variabel yang terdiri dari dua belas indikator dari The Four Forces Model of e-Government yang dikemukakan oleh Wirtz \& Daiser (2015). e-Government di Kabupaten Mamuju dikatakan efektif jika memenuhi indikator-indikator tersebut.

Penelitian tentang e-government pernah dilakukan sebelumnya oleh Nur (2014), dengan judul Penerapan e-Government Publik Pada SKPD Berbasis Pelayanan Di Kota Palu. Hasil penelitian menunjukkan bahwa Pemerintah Kota Palu juga "kurang efektif" menerapkan e- Government, baik dalam pembangunan infrastruktur, pengembangan sumber daya aparatur dalam hal ini SDM Teknologi Informasi, dan perencanaan. Masyarakat sebagai sasaran dari pelaksanaan e-Government di Kota Palu masih belum tersentuh sama sekali khususnya dalam pelayanan pada setiap Satuan Kerja Perangkat Daerah di Kota Palu. Penelitian sebelumnya juga dilakukan oleh Rangkuti (2016), dengan judul Pengelolaan dan Pemanfaatan e- Government pada pemerintah Kota Yogyakarta. Hasil penelitian menunjukkan bahwa e- Government tidak hanya teknologi yang menjadi faktor utama. Selain teknologi menjadi pendorong keberhasilan e-Government, perubahan budaya atau mindset organisasi untuk mendukung dan menerima penggunaan teknologi informasi serta transparansi merupakan dasar menjadi e-Government dapat berjalan dengan baik. 
GJGOPS

P-ISSN: 2614-2120, E-ISSN: 2614-2104

\section{METODE PENELITIAN}

Penelitian ini menggunakan metode pendekatan kualitatif dan jenis penelitian deskriptif. Pengukuran efektivitas penerapan e-Government di Kabupaten Mamuju diperoleh dari pengamatan, diskusi dan melihat dokumen untuk mendapatkan informasi mengenai efektivitas penerapan e-Government di lokasi penelitian dalam kondisi alamiah. Penelitian kualitatif adalah penelitian yang bermaksud untuk memahami fenomena tentang apa yang dialami oleh subyek penelitian, misalnya perilaku, persepsi, motivasi, tindakan, dll., secara holistik (utuh) dan dengan cara deskripsi dalam bentuk kata-kata dan bahasa pada suatu konteks khusus yang alamiah dengan memanfaatkan berbagai metode alamiah (Moleong, 2010). Penelitian ini dilaksanakan di Kabupaten Mamuju, Provinsi Sulawesi Barat yang dimana bagaimana evektifitas penerapan egovernment di Kabupaten Mamuju.

\section{HASIL DAN PEMBAHASAN}

Penerapan e-Government di Kabupaten Mamuju dikatakan efektif apabila memenuhi indikator-indikator dari teori The Four Forces Model of e-Government yang dikemukakan oleh Wirtz dan Daiser yang terdiri dari 4 variabel dan 12 indikator.

Variabel pertama adalah Konvergensi dan Teknologi yang terdiri dari 4 indikator yaitu (1) Konvergensi Teknologi, Informatika dan Komunikasi, adalah memusatkan semua sumber daya teknologi, informatika dan komunikasi baik itu dalam perencanaan, pelaksanaan, pengawasan dalam satu pengelolaan yang dilakukan oleh Pemerintah Kabupaten Mamuju dengan tujuan memudahkan proses pelayanan dari pemerintah dan memberikan pelayanan yang lebih baik kepada masyarakat. Penelitian dilakukan dengan mewawancarai Kepala Bagian Komunikasi, Informatika, Statistik dan Persandian, wawancara dengan Kepala Sub Bagian Pengelolaah Data Elektronik, dan wawancara dengan Operator SIMDA Keuangan di Dinas Pendapatan, Pengelolaan Keuangan dan Aset Daerah (DPPKAD) Kabupaten Mamuju. (2) Virtualisasi Produk dan Layanan, adalah produk pemerintah yang berbentuk elektronik atau konvensional yang dulunya hanya dapat dilihat dan tersimpan dalam komputer, arsip atau bentuk fisik barang, dengan e-government maka semua dibuat dalam bentuk virtual atau digital yang dapat diakses melalui jaringan intranet atau internet baik itu sebuah informasi atau pelayanan. Penelitian dilakukan dengan mewawancarai Kepala Bagian Komunikasi, Informatika, Statistik dan Persandian, dan observasi kegiatan virtualisasi dokumen dan layanan pada ruang IT. (3) Jaringan Berbasis Teknologi, adalah Pemerintah Kabupaten Mamuju membentuk atau mempunyai satu jaringan yang menghubungkan pemerintah dengan pemerintah, pemerintah dengan masyarakat, dan pemerintah dengan pihak ketiga dengan menggunakan perangkat atau teknologi yang terbaru 
dengan tujuan mewujudkan efektif, efisien dan kecepatan proses. Penelitian dilakukan dengan mewawancarai Kepala Bagian Komunikasi, Informatika, Statistik dan Persandian. (4) Dinamika Jaringan dan Inovasi Yang Tinggi Melalui Infrastruktur Yang Kuat, adalah adalah Pemerintah Kabupaten Mamuju dapat memanfaatkan jaringan intranet yang dimiliki dalam mempercepat proses pekerjaan atau pelayanan dari semua OPD dengan menciptakan atau mengadakan aplikasi-aplikasi (software)dan perangkat penunjang sesuai kebutuhan di Kabupaten Mamuju. Penelitian dilakukan dengan mewawancarai Kepala Sub Bagian Pengelolaan Data Elektronik.

Variabel kedua adalah Negara dan Politik yang terdiri dari 4 indikator yaitu (1) Denasionalisasi Sesuai Bidang Politik / Fiskal / Perdagangan Bebas, adalah adalah Pemerintah Kabupaten Mamuju telah melakukan privatisasi bidang politik, keuangan dan perdagangan bebas dimana e-government adalah solusi berbasis internet yang mempercepat proses karena fungsi online itu sendiri yang memungkinkan interaksi pemerintah dengan urusan politik, keuangan, dan masyarakat perdagangan global. Penelitian dilakukan dengan mewawancarai Kepala Bagian Komunikasi, Informatika, Statistik dan Persandian. (2) Tingkat Indebtness Yang Tinggi, adalah adalah bagaimana kondisi keuangan Kabupaten Mamuju apakah e-government bisa berdampak baik karena karakter penghematan anggaran akibat dari otomatisasi, standarisasi atau outsourcing kegiatan dengan menggunakan e-Government. Penelitian dilakukan dengan mewawancarai Kepala Bagian Komunikasi, Informatika, Statistik dan Persandian, dan melakukan studi dokumentasi terhadap RPJPD Mamuju 2005-2025 dan RENSTRA Sekretariat Daerah 2016-2021. (3) Birokrasi Versus Efisiensi Administrasi Publik, adalah harapan pemerintah untuk memangkas birokrasi dan keinginan untuk meningkatkan efisiensi administrasi publik. Dalam konteks ini, eGovernment adalah sistem yang layak karena otomatisasi proses dan standarisasi kapasitas administrasinya. Penelitian dilakukan dengan mewawancarai Kepala Sub Bagian Pengelolaan Data Elektronik, dan melakukan studi dokumentasi terhadap SOP teknis Sub Bagian PDE. (4) Diskontinuitas Karena Orientasi Politik Jangka Pendek, adalah tidak berkesinambungannya penerapan e-Government di Kabupaten Mamuju yang disebabkan karena pengaruh legislatif. Misalnya akibat pergantian legislatif yang mengakibatkan orientasi pemahaman dan penerapan eGovernment menjadi berubah dan tidak sejalan lagi dengan apa yang telah direncanakan dan dilaksanakan sebelumnya. Dengan demikian, diskontinuitas politik merupakan dorongan atau hambatan bernilai negatif. Penelitian dilakukan dengan mewawancarai Kepala Bagian Komunikasi, Informatika, Statistik dan Persandian.

Variabel ketiga adalah Sosial Ekonomi yang terdiri dari 4 indikator yaitu (1) Globalisasi, adalah bagaimana e-Government di Kabupaten 
GJGOPS

P-ISSN: 2614-2120, E-ISSN: 2614-2104

Mamuju dapat menjadi media global dimana perkembangan ekonomi telah mempengaruhi gaya hidup saat ini yang menjadi berbasis elektronik dan teknologi. (2) Sekat Digital, adalah bagaimana e-Government di Kabupaten Mamuju memberikan kesempatan atau peluang yang sama dalam menemukan informasi atau layanan dari pemerintah dengan kualitas yang sama yang diakibatkan dari perbedaan pemahaman digital dari ragam kesenjangan sosio-ekonomi masyarakat Mamuju. (3) Perubahan Demografis, adalah bagaimana masyarakat yang berusia tua di Kabupaten Mamuju yang tidak pernah mendapatkan masa digital yang kemudian saat ini menghadapi zaman informasi dan layanan berbasis digital. (4) Urbanisasi, adalah bagaimana e-government di Mamuju dapat menangani pelayanan terhadap peningkatan jumlah kostumer akibat masyarakat urban dimana akan meningkatkan biaya operasional dan unit pelayanan, solusinya adalah e-Government dengan otomatisasi dan layanan digital dengan biaya yang rendah dan pelayan atau operator yang sedikit. Penelitian dalam variabel ini dilakukan dengan mewawancarai Kepala Bagian Komunikasi, Informatika, Statistik dan Persandian.

Variabel keempat adalah Pemberdayaan Masyarakat yang terdiri dari 4 indikator yaitu (1) Meningkatnya Transparansi dan Akuntabilitas, adalah informasi-informasi dari kegiatan pemerintahan dapat diakses oleh masyarakat Mamuju sebagai suatu akibat dari terlaksananya eGovernment di Kabupaten Mamuju. Penelitian dilakukan dengan mewawancarai Kepala Bagian Komunikasi, Informatika, Statistik dan Persandian. (2) Menghubungkan Warga di Jaringan Sosial dan Komunitas Pemangku Kepentingan Online, adalah bagaimana e-Government di Kabupaten Mamuju dapat menghubungkan masyarakat dan semua pihak yang terkena dampak jaringan online e- government tersebut dalam satu bentuk aplikasi atau fasilitas terbuka seperti media sosial atau sejenisnya dengan tujuan masyarakat mempunyai kekuatan untuk memberikan pengaruh yang cukup besar terhadap proses politik dan administrasi, artinya memperkuat posisi masyarakat. Penelitian dilakukan dengan mewawancarai Kepala Bagian Komunikasi, Informatika, Statistik dan Persandian. (3) Partisipasi Masyarakat, adalah setelah masyarakat di Kabupaten Mamuju sudah memiliki pengaruh terhadap proses politik dan administrasi maka terbuka peluang partisipasi masyarakat dalam isu-isu kebijakan. Penelitian dilakukan dengan mewawancarai Kepala Bagian Komunikasi, Informatika, Statistik dan Persandian. (4) Interaksi Masyarakat - Pemerintah, adalah dengan diterapkannya e-Government di Kabupaten Mamuju akan membentuk satu paradigma baru dimana masyarakat Selayar secara terbuka sudah mempunyai alat atau fasilitas komunikasi untuk berinteraksi dengan pemerintah Kabupaten Mamuju dalam rangka ikut terlibat dalam proses politik dan administrasi atau kegiatan pemerintahan baik itu dalam bentuk kritik, saran, ide atau opini. Penelitian dilakukan dengan mewawancarai Kepala Bagian Komunikasi, Informatika, 
Statistik dan Persandian, dan wawancara dengan responden dari masyarakat umum.

Penelitian ini menunjukkan bahwa penerapan e-Government di Kabupaten Mamuju belum sepenuhnya efektif. Hal ini karena masih terdapat beberapa kejanggalan dalam penerapan e-government di Kabupaten Mamuju. Salah satunya adalah indikator kovergensi dan teknologi yang memang belum memiliki cetak biru e-Government yang dikeluarkan oleh Departemen Komunikasi dan Informatika Tahun 2016. Pengelolaan e-Government di Kabupaten Mamuju masih belum terpusat pada Bagian Kominfo-SP sesuai tupoksinya dalam kelembagaan sesuai Perda Nomor 12 Tahun 2016.

Indikator virtualisasi produk dan layanan juga tidak terpenuhi secara keseluruhan dan belum mencapai separuh urusan layanan OPD yang ada di Kabupaten Mamuju. Dari 36 OPD yang ada di Mamuju, hanya ada 10 website OPD yang teregistrasi termasuk vertikal yang salah satunya terdapat Layanan Pengadaan Secara Elektronik (LPSE), 1 layanan masyarakat yaitu Sistem Informasi tata Ruang (SIMTARU), dan 2 layanan internal pemerintah yaitu Sistem Informasi Kepegawaian (SIMPEG) dan Sistem Informasi Manajemen Daerah (SIMDA).

Indikator jaringan berbasis teknologi juga tidak terpenuhi di Kabupaten Mamuju. Dari hasil penelitian, ditemukan bahwa hanya ada jaringan internal atau intranet dalam lingkup Kantor Sekretariat Daerah / Kantor Bupati Mamuju yang itu pun belum menyeluruh hanya di sekitar ruangan Bagian Kominfo-SP.

Indikator dinamika jaringan dan inovasi yang tinggi melalui infrastruktur yang kuat tidak terpenuhi di Kabupaten Mamuju. Hasil temuan peneliti di lapangan menunjukkan bahwa Sub Bagian Pengelolaan Data Elektronik belum pernah membuat atau mengadakan perangkat lunak atau software maupun perangkat keras atau hardware sebagai inovasi dari jaringan yang dinamis dalam satu infrastruktur eGovernment. Hal ini karena adanya anggapan Sub Bagian Pengelolaan Data Elektronik bahwa jaringan e-Government hanya sebatas website.

Indikator dena sionalisasi sesuai bidang politik / fiskal / perdagangan bebas telah terpenuhi di Kabupaten Mamuju. Hasil temuan peneliti di lapangan menunjukkan bahwa privatisasi dalam bidang eGovernment di Kabupaten Mamuju khususnya dalam bidang politik atau keuangan atau perdagangan telah dilaksanakan sesuai kebutuhan sistem yang dibutuhkan pemerintah pada saat ini.

Indikator tingkat indebtness atau utang yang tinggi tidak terpenuhi di Kabupaten Mamuju. Hasil temuan peneliti di lapangan menunjukkan bahwa belum ada kegiatan e- Government yang berdampak baik terhadap indebtness atau utang negara yang tinggi sebagai akibat dari penghematan anggaran dari otomatisasi, standarisasi atau outsourcing kegiatan dengan menggunakan e-Government. 
GJGOPS

P-ISSN: 2614-2120, E-ISSN: 2614-2104

Indikator birokrasi versus efisiensi administrasi publik tidak terpenuhi di Kabupaten Mamuju. Hasil temuan peneliti di lapangan menunjukkan bahwa e-Government di Kabupaten Mamuju dengan sampel Bagian Komunikasi, Informatika Statistik dan Persandian belum memangkas birokrasi atau meningkatkan efisiensi administrasi publik.

Indikator diskontinuitas karena orientasi politik jangka pendek terpenuhi sebagai hasil negatif di Kabupaten Mamuju. Hal ini dibuktikan dengan belum adanya produk hukum berupa Peraturan Daerah mengenai e-Government di Kabupaten Mamuju hingga saat ini.

Indikator globalisasi sudah terpenuhi di Kabupaten Mamuju. Hasil temuan peneliti di lapangan menunjukkan bahwa e-Government di Kabupaten Mamuju sudah memiliki media global untuk mengikuti gaya hidup saat ini yang berbasis elektronik dan teknologi. Untuk komunikasi jarak jauh Kabupaten Kepulauan Selayar memiliki website dengan alamat http:// http://mamujukab.go.id yang mempunyai fasilitas surat elektronik atau email dan live chat room yang bisa digunakan oleh semua orang dari semua negara.

Indikator sekat digital tidak terpenuhi di Kabupaten Mamuju. Dari hasil penelitian di lapangan peneliti menemukan bahwa banyak kalangan masyarakat yang belum bisa menggunakan fasilitas eGovernment yang disebabkan oleh rendahnya perekonomian sebagian masyarakat, tingkat pengetahuan yang rendah tentang perangkat elektronik dan teknologi terbaru serta terbatasnya infrastruktur yang belum bisa menjangkau beberapa wilayah di Kabupaten Mamuju mengingat bahwa Selayar terdiri atas 11 Kecamatan 2 Pulau.

Indikator perubahan demografis tidak terpenuhi di Kabupaten Mamuju. Dari hasil penelitian di lapangan ditemukan bahwa belum ada produk pemerintah yang berkaitan dengan e-Government baik berupa perangkat lunak atau perangkat keras yang dapat memfasilitasi masalah demografis atau kependudukan di Kabupaten Mamuju dimana masyarakat usia tua dominan belum memahami atau mengenal teknologi saat ini.

Indikator urbanisasi belum secara merata di kabupaten kepulauan Mamuju. Dari hasil penelitian di lapangan, peneliti menemukan bahwa secara nyata kelihatan ada peningkatan masyarakat urban di kota Mamuju. Namun, pada kenyataannya Pemerintah Kabupaten Mamuju belum memiliki fasilitas e-Government untuk melayani banyaknya masyarakat urban dalam semua bidang. Hal ini disebabkan beragamnya aktivitas masyarakat urban tersebut.

Indikator meningkatnya transparansi dan akuntabilitas sudah terpenuhi di Kabupaten Mamuju. Hal ini dapat dilihat dengan adanya publish produk hukum berbagai Peraturan Pemerintah baik itu terkait pelaksanaan APBD maupun informasi pembangunan daerah, semua itu dapat dilihat melalui website portal selayar dengan alamat 
http://Mamujukab.go.id/semua-download.html. Keseluruhan fasilitas ini dapat diakses melalui internet 24 jam setiap hari. Jenis informasi yang dipublish juga sudah memenuhi standar yaitu mendasari Undang-undang Nomor 14 Tahun 2008 tentang Keterbukaan Informasi Publik.

Indikator menghubungkan warga di jaringan sosial dan komunitas pemangku kepentingan online belum terpenuhi di Kabupaten Kepulauan Mamuju. Hasil temuan peneliti di lapangan menunjukkan bahwa belum ada fasilitas atau aplikasi terbuka bagi pemangku kepentingan online terutama semua pihak yang terkena dampak dari fasilitas e-Government ini diantaranya Pemerintah Kabupaten Mamuju sendiri, masyarakat Mamuju, pihak swasta dan pemerintah tingkat provinsi dan kementerian.

Indikator partisipasi masyarakat tidak terpenuhi di Kabupaten Mamuju. Dari hasil penelitian di lapangan peneliti menemukan kurangnya partisipasi masyarakat dalam proses politik dan isu-isu kebijakan sebagai akibat dari penerapan e-Government. Penerapan eGovernment di Kabupaten Mamuju sendiri belum melibatkan masyarakat dalam perencanaan dimana masyarakat adalah sasaran pelayanan dari eGovernment itu sendiri.

Indikator interaksi masyarakat-pemerintah tidak terpenuhi di Kabupaten Mamuju. Dari hasil penelitian melalui wawancara dengan informan Kepala Bagian Komunikasi, Informatika, Statistik dan Persandian, menyatakan bahwa masyarakat Mamuju sudah aktif berinteraksi dengan pemerintah dalam hal ini Bupati dan Wakil Bupati Mamuju melalui kunjungan kerja yang dilaksanakan ke setiap wilayah, namun belum menggunakan e- Government dalam melakukan interaksi. Masyarakat menganggap bahwa respon pemerintah masih sangat kurang yang dibuktikan dengan jarangnya pemerintah aktif dalam grup umum.

\section{PENUTUP}

Rendahnya Efektivitas Penerapan e-Government di Kabupaten Mamuju disebabkan karena kurangnya pemahaman tentang eGovernment pada tingkat eksekutif, pejabat organisasi perangkat daerah, pejabat teknis, dan pejabat legislatif serta sebagian besar masyarakat. Sumber Daya Manusia (SDM) dalam bidang Information Technology (IT) menjadi hambatan yang sangat besar terhadap penerapan e-Government di Kabupaten Mamuju. Disarankan agar Pemerintah Kabupaten Mamuju harus lebih memprioritaskan e-Government dalam pelaksanaan pemerintahan, Memiliki konsep dan perencanaan e-Government dengan mendasari aturan yang ada, Membangun infrastruktur e-Government yang memadai dan sesuai dengan perkembangan teknologi terbaru, Meningkatkan Kapasitas Sumber Daya Aparatur sesuai nomenklatur yang ada dengan mengikuti pendidikan dan pelatihan (Diklat) dalam bidang eGovernment pada semua level atau tingkatan pelaksana e-Government 
Kabupaten Mamuju, Menyediakan Sumber Daya Manusia dalam bidang Information Technology (IT) yang akan sangat berpengaruh dan memiliki feedback atau umpan-balik positif terhadap penerapan e-Government di Kabupaten Mamuju,Memberikan penyuluhan dan sosialisasi kepada masyarakat mengenai teknologi dan informatika sehingga membentuk masyarakat yang cerdas dan dapat mengikuti zaman berbasis digital saat ini.

\section{REFERENSI}

Departemen Komunikasi dan Informatika. (2006). Cetak Biru Sistem Aplikasi e-Government bagi Pemerintah Pusat dan Daerah. Jakarta. Departemen Komunikasi dan Informatika.

Indrajit R.E. (2006). Electronic Government (Strategi Pembangunan dan Pengembangan Sistem Pelayanan Publik Berbasis Teknologi Digital). Yogyakarta : ANDI.

Instruksi Presiden Nomor 3 Tahun 2003 Tentang Kebijakan dan Strategi Nasional Pengembangan e-Government.

KeputusanMenkominfo Nomor 55 Tahun 2003 Tentang Pedoman Pengembangan Infrastruktur portal Pemerintah.

Moleong, J.L. (2007). Metodologi Penelitian Kualitatif. Bandung : PT. Remaja Rosdakarya Offset.

Nur E. (2014). Penerapan E-Government Publik Pada Setiap SKPD Berbasis Pelayanan Di Kota Palu. Jurnal Penelitian Komunikasi dan Opini Publik, Volume 18 Nomor 3 Desember 2014.

Perda Nomor 12 Tahun 2016 tentang Pembentukan dan Susunan Perangkat Daerah Kabupaten Kepulauan Selayar.

Undang-Undang Nomor 14 Tahun 2008 Tentang Keterbukaan Informasi Publik.

Rangkuti G.E. (2016). Pengelolaan Dan Pemanfaatan E-Government Pada Pemerintah Kota Yogyakarta. Tidak Diterbitkan.

Wirtz B.W. \& Daiser P. (2015). E-Government: Strategy Process Instruments. Text Book For The Digital Society. Available from: http://berndwirtz.com/downloads/WirtzDaiser_2015 Government.pdf. 